\title{
Issues of Rarity in the Treasure Economy
}

\author{
Irina Datchenko ${ }^{1}$, Natalia Alimova ${ }^{2}$, Svetlana Popova, ${ }^{2,}$, and Tatiana Sichkar ${ }^{2}$ \\ ${ }^{1}$ Moscow International Academy for Continuous Education and Social Studies \\ «Civilizational Renewal», Moscow, Russia \\ ${ }^{2}$ Institute of World Civilizations, Moscow, Russia
}

\begin{abstract}
The article examines the changes occurring in society as evidenced by the crisis of 2020. In this regard, the authors explore such formations as the emerging economy of impressions (categories: raw materials, goods, services, impressions) and the economy of riches (categories: raw materials, goods, services, impressions, rarity). The formulae for the types of activities that constitute the economy of impressions and the economy of rarity are defined. The analysis of the growth prospects of the economies of some countries is carried out. The comparative analysis of consumer demand in Russia and its areas showed that during the pandemic, there is a tendency of changing the values system in the political and socio-economic reality of the individual, which is reflected in its various practical needs and relations to the surrounding resources, goods and services: service and entertainment industries are suffering heavy losses, some segments of business experiencing growth of consumer activity: online shopping, delivery services, educational and entertainment services, remote banking It is stated that nowadays the rarity category, such as real communication, is gaining priority in the economy of treasure. Conducted a comparative analysis of some of the countries and Russian areas most similar levels of economic development, as a basis for meaningful conclusions that interpersonal relationships and communication is a category of rarity and has a special value in this pandemic period, representing the economy of treasures.
\end{abstract}

\section{Introduction}

Today's rapidly changing reality is constantly faced with the problem of crisis phenomena, which in one way or another affect various socio-economic formations, including the impression economy and the economy of treasures.

According to the theorizing of D. Pine and D. Gilmore, the idea of the «impression economy» is a reflection of a new socio-economic reality beyond the three classical economic categories: «raw material - product - service» [1].

\footnotetext{
* Corresponding author: svetpopzhuk@yandex.ru
} 


\section{Results and discussion}

Impressions become an independent product and object of purchase and sale, which entails the emergence of a new economic category - «impression» and the emphasis of the share of added value on «impression» (Fig. 1) [2].

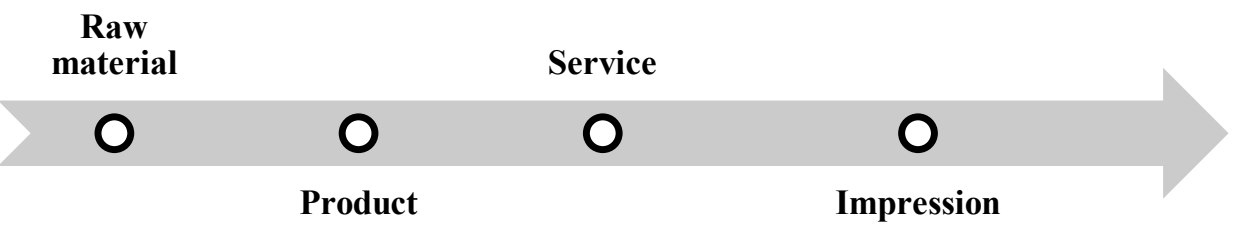

Fig. 1. Categories of the impression economy (compiled by the authors)

Each type of activity related to the impression economy is a function in the set of the following variables:

$$
\mathrm{EoI}=\mathrm{f}(\mathrm{MC} ; \mathrm{LE} ; \mathrm{IE} ; \mathrm{IDC})(1),
$$

- EoI - economics of impressions;

- MC - the cost of manufacturing a product, good or service;

- LE - logistics expenses;

- IE - impression expenses;

- IDC - impression delivery costs.

Homogeneity of achievements in large-scale research areas is fixed by the creation of highly intellectual products, which allows us to refer to the transition of society (civilization) to a new level in the management systems of the state, society, the economy. However, the emerging contradictions between the development of scientific and technological progress and the new values of a certain resource (material or intangible) for a particular consumer creates the preconditions for the formation and development of a new economic formation - the economy of treasure [3].

The past year 2020 in relation to the spread of the COVID-19 pandemic has brought to light a global trend of changing value systems in the political and socio-economic reality of human beings, outlining their various practical requirements and attitudes toward the external resources, goods and services (Fig. 2).

\begin{tabular}{|ccccc|}
$\begin{array}{c}\text { Raw } \\
\text { material }\end{array}$ & \multicolumn{3}{c}{ Service } & Rarity \\
\hline 0 & 0 & 0 & 0 & 0 \\
\hline & Product & & Impression & \\
\hline
\end{tabular}

Fig. 2. Categories of the Treasure Economy (compiled by the authors)

According to Figure 2, the concept of "rarity" represents the importance of a product, good, or service to a particular individual at a particular point in time.

Accordingly, the activities associated with the treasure economy will be represented by the following function:

$$
\mathrm{EoT}=\mathrm{f}(\mathrm{MC} ; \mathrm{LE} ; \mathrm{IE} ; \mathrm{IDC} ; \mathrm{CRR})(2) \text {, }
$$


- TE - treasure economy;

- $\mathrm{MC}$ - the cost of manufacturing a product, good or service;

- LE - logistics expenses;

- IE - impression expenses;

- IDC - impression provision costs.

- CRR - the cost of providing a rare resource.

The pandemic has had the highest impact on the youth, the poor, the informally employed, and those employed in the service sector.

After the global economy declined by $3.5 \%$ in 2020 , it is projected to expand by $5.5 \%$ in 2021 and $4.2 \%$ in 2022 (Table 1) [4].

Table 1. Outlook for the economic expansion of some countries (real GDP, annual percentage shift)

\begin{tabular}{|l|c|c|c|c|}
\hline \multirow{2}{*}{ Country } & \multicolumn{2}{c|}{ Data } & \multicolumn{2}{c|}{ Outlook } \\
\cline { 2 - 5 } Advanced economies & 2019 & 2020 & 2021 & 2022 \\
\hline USA & 1,6 & $-4,9$ & 4,3 & 3,1 \\
\hline Germany & 2,2 & $-3,4$ & 5,1 & 2,5 \\
\hline France & 0,6 & $-5,4$ & 3,5 & 3,1 \\
\hline Japan & 1,5 & $-9,0$ & 5,5 & 4,1 \\
\hline United Kingdom & 0,3 & $-5,1$ & 3,1 & 5,4 \\
\hline Canada & 1,4 & $-10,0$ & 4,5 & 5,0 \\
\hline Emergingand Developing Economies & 1,9 & $-5,5$ & 3,6 & 4,1 \\
\hline China & 3,6 & $-2,4$ & 6,3 & 5,0 \\
\hline India & 6,0 & 2,3 & 8,1 & 5,6 \\
\hline Russia & 4,2 & $-8,0$ & 11,5 & 6,8 \\
\hline Brazil & 1,3 & $-3,6$ & 3,0 & 3,9 \\
\hline
\end{tabular}

According to Table 1, there is a decline in economic growth for all countries represented in 2020, with significant declines in France (-9.0\%) and the United Kingdom ($10.0 \%$ ). If global activity recovers, global trade volumes are projected to grow by about $8 \%$ in 2021 and then decline to $6 \%$ in 2022 . Services are expected to recover more slowly than manufacturing due to the gradual opening of borders of several countries closed because of the COVID-19 pandemic.

Advanced economies were generally able to provide fiscal support to households and firms (tax deferrals, government guarantees, quasi-fiscal operations, etc.), central banks also implemented support through expanded asset purchase programs, lending financing mechanisms and lower interest rates. Projected output losses compared to pre-pandemic forecasts are smaller for advanced economies than for other countries. Recovery paths vary within the group: The U.S. and Japan are predicted to regain the level of activity they had in late 2019 in the second half of 2021, while in the European Union and the United Kingdom, economic growth is projected to remain below pre-pandemic levels.

Emerging and developing economies are predicted to recover differently. For example, significant differentiation is anticipated between China's economy and the economies of other countries in this group. China has taken effective containment measures to spread the COVID-19 pandemic, including public investment and central bank liquidity support, which have contributed to the country's rapid economic recovery. The oil-exporting and tourism-oriented countries in this group face particular difficulties in recovering their economies, primarily due to the slow process of opening foreign borders and the containment of oil prices. This group includes the economy of India, which is the sixth 
largest GDP economy in the world. In 2019, India's GDP was \$2.9 trillion, and in 2020 it declined by 0.3 to $\$ 2.6$ trillion. This decline is insignificant because the country's economy is based on sustained government-industry cooperation and reliance on advanced and innovative technology.

Asia's largest economy, China, is the only exception among the countries affected by the pandemic. Chinese GDP not only remained at the same level, but even increased in volume (for comparison, in 2019 China's GDP was \$14.4 trillion, in 2020 - \$14.8 trillion) [5].

As for Russia, GDP reached $\$ 1.464$ trillion in 2020 , compared to $\$ 1.699$ trillion in 2019. In 2020, Russia faced not only the COVID-19 pandemic, but also other crises, such as the fall in oil prices and oil production cuts under the OPEC agreement. However, the downturn was smaller than in most other states, largely due to various state support measures aimed at businesses and the population, as well as limited use of nationwide lockdowns. In addition, Russia has traditionally had a large public sector, which has been less affected by COVID-19 than the service sector and small businesses. Russia's GDP is projected to grow by $2.9 \%$ in 2021 as a result of increased oil production, the recovery of the global economy, and the removal of domestic restrictions related to the coronavirus pandemic [5].

It should be stressed that the COVID-19 pandemic affected consumer demand in all market sectors. It mainly affected the offline industry: tourism, cafes and restaurants, cosmetics and styling, concerts and other mass entertainment events, medical services. The sharp decline in the service sector (the turnover was about $60 \%$ of the level of 2019) was observed during the spring quarantine in 2020 , in the second wave the decrease was not so deep (up to $85 \%$ of the level of 2019).

It is worth noting that the situation in the regional context in Russia was extremely different, which is due to the quarantine measures in separate regions, which were varied in the timing and types of economic restrictions. Thus, consumer demand fell strongest in the Republic of North Ossetia-Alania. In this region, according to statistics, the spending of the population decreased by $16.4 \%$. In addition to North Ossetia, the most affected regions in this aspect are the following: Republic of Sakha (Yakutia) (-15.1\%), Primorsky Area ($13.1 \%)$, Republic of Dagestan (-12.2\%), Karachay-Cherkess Republic (-12.1\%), Omsk Oblast (-11.7\%), Kabardino-Balkar Republic (-11.6\%), the Republic of Crimea $(-11.3 \%)$, the Stavropol Area (-11.3\%), the Bryansk Region (-11.1\%) and the Sverdlovsk Region ($10 \%)[6]$.

According to the portal of state statistics EMISS, the index of physical volume of the turnover of the restaurant business for 9 months of 2020 decreased by $22.8 \%$ compared with last year's figures, which is about 947.5 billion rubles. [7]. The strongest decline in the restaurant business market was in April-June 2020. It fell by $44-53 \%$ to $63-78$ billion rubles, depending on the month. Only in August the market started to demonstrate the first signs of recovery: the turnover increased to 118.7 billion rubles, which, nevertheless, was $18.7 \%$ lower than in 2019 .

In September-October 2020, the revenue of Russian theaters and cinemas revealed a decline of about 1.5 times compared to 2019 .

Tourist services suffered the most in 2020 (46.9\% of the pre-pandemic level); of domestic services - bathhouses and saunas $-64.9 \%$, laundries and dry-cleaners $-68.6 \%$.

In the beauty industry there was also a decline. Interest in manicure in a full-service beauty center also declined by $20 \%$. There was a $26 \%$ drop in demand to rent offices in hairstyling studios and beauty studios. Interest in getting a pedicure also decreased $(-32 \%)$. But significantly increased the demand for self-training to remove nail polish and gellacquer - in the first case by $73 \%$, in the second $-95 \%$. There was a new trend in this kind 
of service - beauty-taxi. Demand for «beauty salon in the car» services, where you can get a manicure or haircut, increased during the pandemic by $13133 \%$.

Consumer values and habits have altered due to the COVID-19 pandemic. While the service and entertainment industries are suffering heavy losses, some business segments are experiencing growth in consumer activity: online shopping, delivery services (food, restaurants, etc.), educational and entertainment services, remote banking and insurance, telemedicine, health and hygiene products and services. For example, in chain stores sales of bleach and floor cleaning products increased by $21 \%$, soap sales increased by $19 \%$, and sales of universal household cleaning products increased by $13 \%$ [8]. According to research of Nielsen, $21 \%$ of the interrogated Russians regularly read online books, $20 \%$ began to spend time in social networks more often, $18 \%$ watched video, $12 \%$ listened to music and radio [9]. The number of requests for telemedicine in 2020 increased 64 times compared to 2019. The most demanded telemedicine services were for residents of Moscow - $30 \%$ of the total number of appeals, for residents of St. Petersburg - 9\%, Altai area - 5\%, Smolensk area $-4 \%[10]$.

The Chukotka Autonomous District stands out against the background of the above regions, where the growth in consumer demand was $+3.1 \%$, which it gained due to the selfisolation regime. Probably, in ordinary years the population of Chukotka in summer time massively left this harsh and remote region for other the RF subjects, where people spent their money, but now Chukotka residents had to arrange their leisure time at home, which predetermined the growth of the local demand.

It should be noted that cultural institutions in Russian regions have temporarily moved to the virtual space because of the pandemic, opening access to hundreds of theatrical performances, musical concerts, excursions, exhibitions and master classes to all comers without time or space restrictions.

The consumer market has already changed seriously, and consumers have to adapt to the new conditions: giving preference to online services (shopping, education, sports, etc., as well as non-work activities, such as communicating with friends) - this shows the importance of personalization in the consumption of goods or services by the population, as a manifestation of the impression economy [11].

At the same time, it must be stated that nowadays the economy of treasure acquires priority, as the category of rarity of certain resources appears in the pandemic.

For an individual and society as a whole the category of rarity is expressed in the fact that the increase in demand for online services cannot compensate for people's communication in the real environment (with friends, when getting medical, tourist services and buying goods, when visiting cultural events, baths and saunas, beauty studios, etc.), which in the pandemic period becomes significant. Real communication implies communication between people, during which there is psychological contact through mutual influence, -understanding, -experience, and in the exchange of information, thoughts, ideas, emotions. It is the real communication contributes to the development and formation of a person, personality. Thus, in this case, rarity, as a category of the treasure economy, begins to speak as the value of real relationships and is defined as a willingness to pay for real communication (depending on gender and age characteristics).

To reflect the impact of the pandemic on the economic situation in some countries of the world and Russian regions, the following comparison criteria were selected - GDP of the world and GRP of the subjects of the Russian Federation, most similar by the level of economic development. By random sampling we took for comparison the countries and the regions of the Russian Federation, presented in Table 2. 
Table 2. Comparison of some countries of the world and subjects of the Russian Federation

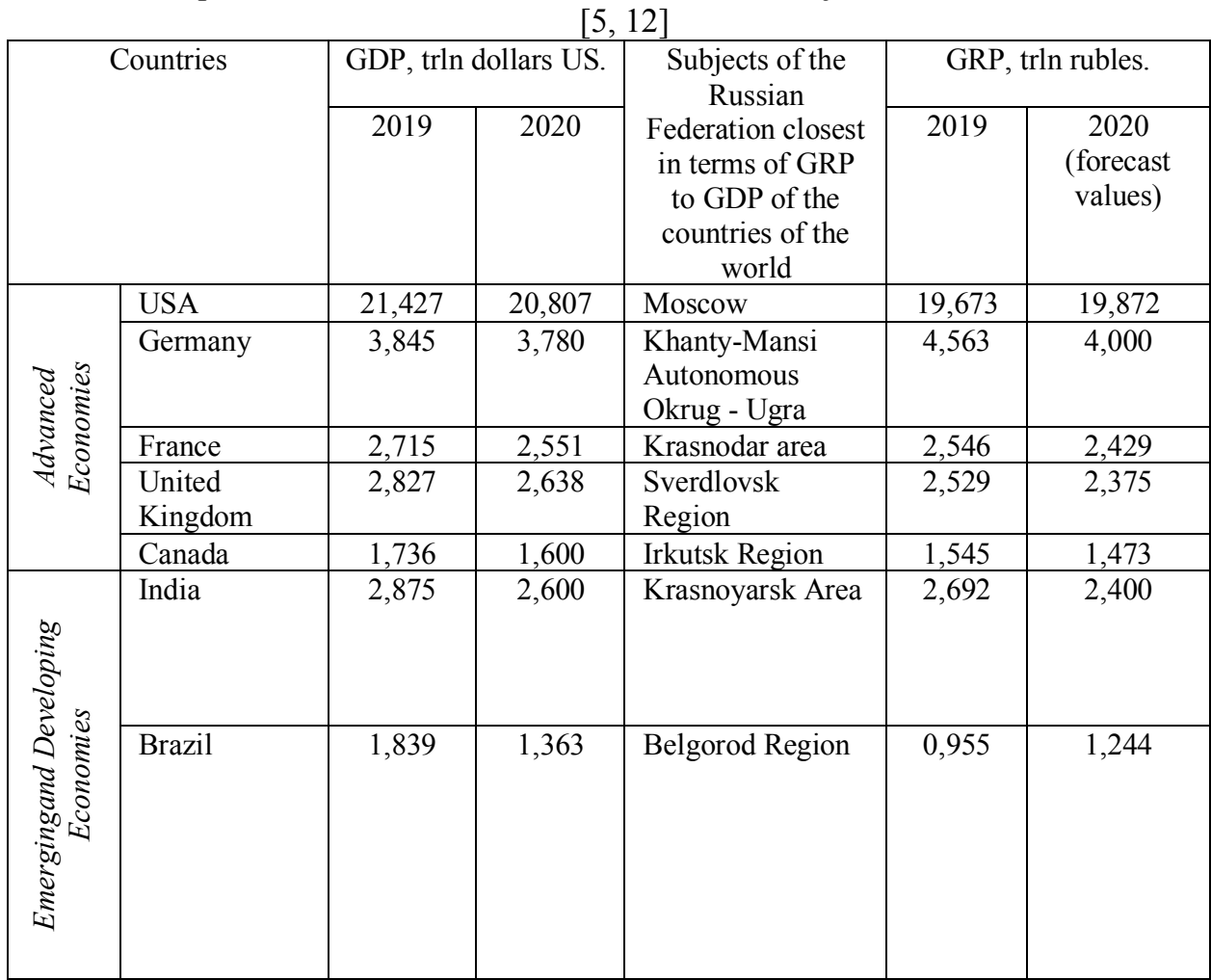

According to Table 2, the GDP of all reviewed countries decreased in 2020 compared to 2019. On the contrary, GRP of the considered subjects of the Russian Federation close to the GDP of the countries on the contrary increased in 2020 in Moscow and Belgorod region, in other regions there is a slight decrease in this indicator. The active work of the Government of the Russian Federation on the development of the economy and social sphere of the regions, constructive cooperation with regional business structures and the population will help to overcome the crisis caused by the pandemic and ensure sustainable economic growth and increase the well-being of citizens in the coming years.

\section{Conclusion}

Finally, the following conclusions could be evaluated that the development of the country and the region, accompanied by the growth of GDP and GRP respectively, will have a positive impact on the development of society and the scientific and technological component, increasing the requirements for interpersonal communications, which are associated with social, political and economic processes, an increased number of business contacts in a variety of areas of modern social life. Interpersonal relations and communications are precisely a category of rarity and have a special value in this pandemic period, representing an economy of treasure. 


\section{References}

1. The Experience Economy: Work is Theatre \& Every Business a Stage, B. Joseph Pine, James H. Gilmore, 1999.

2. T.V. Sichkar. The Eurasian Scientific Journal, 10, Issue 1, 31 (2018).

3. T.V. Sichkar. Economika sokrovichsh i globalnye problem chelovechestva (In Russ.) / Monographiya / M.: Publishing House «IMC», 2020. - 193 p.

4. World Economic Outlook Update. January 2021 // International Monetary Fund. // URL: https://www.imf.org/en/Publications/WEO/Issues/2021/01/26/2021-world-economicoutlook-update (accessed 08.02.2021).

5. World Economy Rankings 2021, Table GDP of the World// URL: https://basetop.ru/rejting-ekonomik-mira-2021-tablitsa-vvp-stran-mira/.

6. Federal State Statistics Service // URL: https://rosstat.gov.ru/statistic (accessed 08.02.2021).

7. EMISS state statistics portal // URL: https://rosstat.gov.ru/emiss (accessed 08.12.2021).

8. Demand for cleaning supplies, cosmetics and networking equipment has increased // URL: $\quad$ https://rg.ru/2020/04/27/vyros-spros-na-sredstva-dlia-uborki-kosmetiku-ioborudovanie-dlia-vyhoda-v-set.html (accessed 12.02.2021).

9. Nielsen // URL: https://www.nielsen.com/ru/ru/ (accessed 12.02.2021).

10. The popularity of telemedicine in 2020 increased by 64 times (In Russ.) // URL: https://www.mk.ru/social/2021/02/10/populyarnost-telemediciny-v-2020-godu-vyroslav-64-raza.html (accessed 15.02.2021).

11. O.N. Slobotchikov, K.A. Kirsanov, S.A. Popova. The Eurasian Scientific Journal, 12, Issue 1, 64 (2020).

12. Valovoi regionalnyj product po sub'ektam Rossiyskoj Federacii (In Russ.) // Natsional'nye scheta // URL: https://rosstat.gov.ru/accounts (accessed 04.03.2021). 